\title{
The Never Ending Cold War Over Energy and the Cyprus Issue
}

\author{
George Koukoudakis \\ Military Academy, Vari, Greece
}

\begin{abstract}
Within the context of a never ended Cold War in the energy field, the discoveries of natural gas resources in the Southern Eastern Mediterranean definitely create new impetus for the resolution of the longstanding Cyprus issues. After the failure of the last negotiations talks in July 2017, there is common strategic reason that calls for a mutually accepted resolution among all the parties involved. The situation calls to put aside national feelings and the burden of history and move forward. What is of crucial importance is not only the maintenance of international peace and regional stability but also the enhancement of the welfare of the people of this turbulent region. Whether the path of reason will be followed is remained to be seen.
\end{abstract}

Keywords: energy, Cold War, Cyprus, security

\section{Introduction}

It is more than obvious that since the end of the Cold War, a competition keeps on going between Russia and the United States of America (USA). Energy seems to be the leading field in this competition. As was the case in the past, European continent, mostly the area cover by the European Union (EU) member states, seems to constitute the disputed area where both competitors want to enhance their influence. By taking advantage of Europe's energy dependence are trying to influence the energy policy directions of the EU and its members in such a way as to prevent each other from enhancing their position. Washington from one hand is trying to limit Russia's dominant position in the European natural gas market, and thus, curtail Moscow's energy bargain card vis a vis its North Atlantic Treaty Organization (NATO) and European allies. On the other hand, Russia is trying to maintain and further enhance its advantage in the European energy market from which it derives significant economic and diplomatic leverage.

From its part the EU, an energy dependent region is trying to diversify the roots and the sources of its energy supply. The Russian-Ukrainian crisis of 2006 and 2009 exercised great pressure on EU's energy security. As a result with the Prague Declaration of 2009, it highlighted the importance of the creation of an energy corridor that is going to transit energy sources, mainly gas, from the Caspian region to its own territory bypassing Russia. United States (U.S.) foreign policy seems to be supporting this project. The Trans Anatolian Pipeline and the Trans Adriatic Pipeline are the energy projects that so far constitute the realization of the Southern Corridor. The capacity of the so called "Southern Corridor," however, does not suffice to satisfy the constantly increasing energy needs of the EU. The discoveries of big quantities of natural gas off shore of Israel, the Republic of Cyprus (RoC), and Egypt create the potential for the creation of "the Eastern Mediterranean" energy corridor that is going to contribute significantly to the enhancement of the energy security of the EU. Regardless of whether this new corridor is going to be constructed passing by Turkey, Greece, or even Egypt,

George Koukoudakis, Ph.D., Military Academy of Greece. 
its realization requires the resolution of the longstanding Cyprus issue. This article argues that within the context of this "never ended Cold War" and the prospects of the Energy security of the EU, the timing of resolving the Cyprus issue seems appropriate.

\section{Energy Security of the EU and the Wider Geopolitical Context}

EU is in a high degree an energy dependent area (Koukoudakis, 2017a). It is also the largest energy importer in the world (European Commission, 2015a). Its own sources, two thirds of which are located in five of its 28 member states, can hardly satisfy $48 \%$ of its energy consumption (European Commission, 2011). It is also worth to be noted that the external dependence of the EU on oil and gas is estimated to $83.5 \%$ and $64.2 \%$ accordingly (European Commission, 2011). Furthermore, given the constantly increasing demand for energy among the EU member states, it is estimated that by 2030 the external energy dependence of the EU will reached 75\% (Gawdat, 2006). At present, the EU imports most of its energy resources from three main areas. These areas are the North Sea, Russia, and the Middle East. This situation becomes further worrying if one bears in mind that the lion's share of the energy supplies of the EU is hold by two main regions: Russia and its near abroad region and the Middle East. The situation is expected to deteriorate given that oil production of Northern Europe is decreasing making, thus the EU more dependent on Russia and the Middle East for its energy supply (Smith, 2010).

Russian oil exports to the EU and oil exports to the EU that are dependent on the Russian export system amount to at least $4.44 \mathrm{mb} / \mathrm{d}$ that are equal to $34.71 \%$ of the EU's oil consumption. Six member states depend from Russia as single external supplier for their entire gas imports and three of them use natural gas for more than a quarter of their total energy needs (EU, 2015).

According to the European Commission, in 2013 energy supplies from Russia accounted for $39 \%$ of EU natural gas imports or $27 \%$ of EU gas consumption and Russia exported $71 \%$ of its gas to Europe with the largest volumes to Germany and Italy (European Commission, 2014). Furthermore, almost 50\% of EU's gas consumption is transited via the soviet-made Ukrainian gas transmission system (Tsakiris, 2014). In particular, Russian gas is delivered through Ukraine, to 18 EU member states. Simultaneously, the EU imports $35 \%$ of its crude oil supplies from the Middle East (European Commission, 2011).

The situation described above renders the energy security of the EU vulnerable to political developments and military crisis in those areas. The Rusian-Ukranian crisis of 2006, 2009, and of 2014-2015 are such examples. The turbulent area of the wider Middle East is also a point of reference. This is not only due to the traditional Arab-Israeli conflict and the events in the Persian Gulf in the 1990s and 2000s, but also to the social uprising within the context of the "Arab Spring" movement and the actions of the so called "Islamic State of Iraq and the Levant (ISIL)". In addition, tentative relations between Iran and Saudi Arabia greatly increase uncertainty. Consequently, the ability of policy planners and strategists in oil-consuming nations to control risk is limited at best (Cordesman \& Al-Rodhan, 2006).

\section{EU’s Energy Security Policy}

As a result over the last 15 years, the EU is trying to form a coherent energy policy in order to protect its energy security from any disruption. Thus, it presented its first green paper entitled "Towards a European strategy for the security of energy supply (European Commission, 2000)". The European security strategy of 2003 also presented energy security as a basic concern (EU, 2003). On March 8, 2006, the European 
Commission issued a new green paper on energy entitled "A European strategy for sustainable, competitive and secure energy (European Commission, 2006)." One basic target set as a strategic priority for the EU on this green paper was the diversification of routes and sources of supply. Within this context, the EU with the Prague Declaration of 2009 highlighted the importance for the creation of a corridor of supply of energy to its territory that is going to bypass Russia, this time, and transit energy sources from the Caspian region to Europe (EU, 2009).

\section{The Never Ended Cold War Over Energy}

European countries decided to diversify suppliers and the roots of energy supply dates back in the 1970s. The world oil crisis that stemmed from the Middle East was the main triggering mechanism. At the same time, the Organization of the Petroleum Exporting Countries (OPEC) emerged as a basic actor in the international politics of energy. Within this context, the energy base of the neighboring Soviet Union was the main credible alternative. The ease of relations between the West and the East within the context of Détente facilitated such development.

The U.S., however, was never pleased with the expansion of energy relations between the Soviet Union and its European NATO allies. Between 1984 and 1985, for example, Washington tried to prevent western European countries, including the United Kingdom (UK), from supplying steel pipe for Russian oil and gas shipment to Europe. General electric was also barred by Reagan Administration from selling compressors and pumps for a gas pipeline to the Soviet Union or Germany (Smith, 2010).

After the end of the Cold War, the USA is also trying to curtail the energy dependence of European countries on Russian energy sources. Beginning in 1990, the U.S. government had an active program to assist the new Eastern and Central European democracies in developing self-sustaining energy efficiency projects (Smith, 2010). It is more than obvious that Washington is seriously worrying that Moscow will use European energy dependence in order to prevent further transatlantic co-operation and negatively influence NATO policy choices on the European continent. At the same time, Russia is also expected to use this situation in order to enhance its economic power and to expand its exports of military equipment to Europe. This also explains that in 2011, the Bureau of Energy Resources (ENR) was created with mission to lead "the Department of State's efforts to forge international energy policy, strengthen U.S. and global energy security, and respond to energy challenges from around the world that affect U.S. economic policy and national security (U.S. Department of State, 2017)".

As a result, U.S. foreign policy is trying to play a role in pipeline politics. Its main goal is to support the construction of no Russian interest pipelines that bypass Russia and transport oil and gas to Europe.

Within this context, the U.S. supported the Baku-Tbilisi Ceyhan (BTC) oil pipeline that Turkey proposed in 1992. The BTC pipeline is operational since 2005 and is delivering oil from the Caspian region to Europe that is carried by tankers. Washington also supported the Nabucco gas pipeline that was designed to transport Caspian gas to European markets via Turkey and the Balkans. The project, however, was declined. It was replaced by the Trans Anatolian Pipeline (TANAP) which has also received U.S. and EU support. U.S. diplomacy also exercised pressure to postpone the, Russian interest, South-Stream pipeline.

All in all, U.S. support for non-Russian pipelines shipping oil and gas to Europe has been obvious. However, competition with Russia in many instances has been strong. It seems that the Cold War over energy has never ended and that Europe is once again in the epicenter of this antagonism. 
The TANAP and Trans Adriatic Pipeline (TAP) projects however do not seem to drastically curtail EU's energy dependence on Russia. It is common knowledge that its transport capacity, as it will be presented below, does not suffice to fulfill EU energy needs. Within this context, the creation of an Eastern-Mediterranean gas corridor seems to serve both EU and U.S. interests. Thus, the resolution of the Cyprus problem seems also to contribute towards this goal.

The following analysis aims to show that regardless of the export root that the gas from Cyprus and Israel will take, either via Turkey, Greece or Egypt, the settlement of the Cyprus issue is a crucial precondition for the long-term sustainability of this project. In other words, the resolution of the Cyprus issue should not only provide a viable and functional settlement for the safety of the investment but will also serve as an extra guarantee for the protection of the energy security of the EU and geostrategic interests of U.S.

\section{Energy Politics and the Cyprus Issue}

In 2009, Israel discovered important gas resources within its Exclusive Economic Zone (EEZ) in the so called "Leviathan" sea field. The exploitation of these resources was expected to start in 2017. Thanks to this discovery, Israel will become a net exporter of natural gaz. In 2011, the RoC also discovered natural gas resources in its EEZ in the so called "Aphrodite" sea field. Despite initial optimism in October of 2013 Noble Energy, the company in charge of the explorations announced that the natural gas reserves in Aphrodite sea field are 3.6 to six trillion cubic feet which is less than 5.5 billion, quantity necessary to build an economically viable Liquefied Natural Gas (LNG) facility (Savvides, 2015). This implies that the RoC has to expand its exploration for the discoveries of more gas. Something that Nicosia did in 2017. Alternatively, the RoC will have to co-operate with Israel in order to supplement quantities for the reconstruction of an economically viable LNG or even to co-export its natural gas. Indeed, both countries signed a bilateral agreement in 2010 on energy co-operation.

A new important factor in the geopolitics of the region was added with the discoveries of great quantity of natural gas offshore of Egypt in 2015. Since then, various discussions have taken place over the export root of Cypriot and Israeli gas resources. So far, three no necessarily mutually exclusive options have been presented.

\section{The First Option: Via Turkey}

The first option, which is commercially preferable than all the others, is to combine the gas resources of Israel and Cyprus, at least initially, to process them jointly and to involve Turkey as both customer and conveyor. In case, however, the RoC will not support such an option, Israel gas alone could be transported through that root. The political and economic benefits of such a choice are important. Due to the proximity of Leviathan and Aphrodite fields to Turkey, the transport cost will be relatively low. At the same time, Turkey will be a great customer of this gas given that it constitutes "one of the fastest growing gas markets in the world, with demand projected to increase from $43.1 \mathrm{bcm}$ in 2012 to $62 \mathrm{bcm}$ in 2020, and $69 \mathrm{bcm}$ in 2030 (Roberts, 2013).

Simultaneously, in Turkey, there is already an important network of gas and oil pipelines that are operational. As far as gas is concerned (Republic of Turkey Ministry Foreign Affairs, 2017) ${ }^{1}$, the "Blue Stream

\footnotetext{
${ }^{1}$ There are also various oil pipelines. In 2006, the Baku-Tbilisi-Ceyhan (BTC) was opened. It is a pipeline that transfers oil from Azerbaijan via Georgia to the Turkish port of Ceyhan. The significance of this oil pipeline lies on the fact that it transfers Caspian oil without going through Russia. Finally of great strategic importance for the energy security of Europe is that every year some 10.000 tankers pass the Bosphorous strait, which connects the Black Sea with the Mediterranean.
} 
for Russian gas" is operating since 2003. It is an undersea pipeline that connects Russia with the Turkish port of Samsun. The potential of this pipeline and as a result its strategic importance is that Russian gas can be transported to Europe without going through Ukraine. Furthermore, in 2007, the interconnector to Greece was opened. It is an interconnector pipeline that carries Caspian gas via Turkey to Greece. Its importance lies on the fact that for the first time gas from the Caspian reaches Europe without crossing Russian territory (Barysch, 2007). As a result, a connection can be made Cyprus-Israel-Turkey-Europe.

On a political level, this prospect will definitely enhance the Southern Energy Corridor project of the EU given that, as was stated above, Caspian gas would cover a small fraction of overall European imports, as the BTE line will convey only, 10-15 bcm per year of Azeri gas to Europe, a small volume compared to the EU's projected future annual consumption of $700 \mathrm{bcm}$ (Tekin \& Williams, 2009).

Simultaneously, within the context of the cold war between the U.S. and Russia over energy this new gas quantity in Southeastern Mediterranean can serve U.S. and NATO interests. At the moment, Turkey's dependence on Russian gas is estimated at 63\% (Kaysi, 2011). As a result, Russia can have diplomatic leverage over Turkey which is a NATO member with special significance for the U.S. geostrategic interests (Flanagan \& Brannen, 2008). Within this context and given the special Israel-U.S. relationship, the transportation of Israel gas through Turkey will definitely serve U.S. interests because it will curtail Russian influence. In addition, given that Iran is the second natural gas exporter to Turkey, such a development will also imply loses for Iran, Israel's main regional competitor (Babaly, 2012). Finally, such a development will also be in Turkey's interest and especially for its aspirations to evolve as an energy-hub (Shaffer, 2006).

\section{Limitations}

However, this option faces some serious geopolitical obstacles and limitations. The most serious of such obstacles is the Cyprus issue. The transportation of Israeli gas to Turkey by undersea pipeline requires the direct approval of the government of the RoC. Such a possibility seems unlikely without the resolution of the Cyprus Issue given that Turkey illegally occupies $37 \%$ of the territory of the RoC and illegally maintains occupation forces.

Furthermore, EU-Turkish relations are an area of great concern. Many analysts on a European level are afraid of Turkey using EU's energy dependence as leverage for its accession despite its great democratic shortcomings (Euractive, 2009). In addition, the fact that the RoC is already and a full member of the EU should not be overestimated given its veto power towards Turkish accession process.

Furthermore, the internal political situation in Turkey seems to be worsening as a result of the justice and development Party's (AKP) conservative-Islamisation policies that have resulted in a polarized Turkish society along religious, secular, and ethnic lines. The Gezi Park protests of 2013 constitute a clear indication of this development (Koukoudakis \& Pieper, 2014). On top of that the Turkish state and the Kurdish Worker's Party (PKK) are once again, since July 2015, at war. As a result, in July and August 2015, PKK guerrillas attacked Turkish oil and gas pipelines on at least four occasions and a train carrying pipes for a new gas line from Azerbaijan on a fifth occasion (Roberts, 2015). Even worst a failed coup attempt against the president of the Turkish Republic himself on July 2016 that claimed the lives of few hundred was another indication of the fragile internal political situation in Turkey that can easily affect EU-Turkish relations in general and the energy security of Europe in particular (Koukoudakis, 2017b). 
In addition, Turkish Foreign Policy (TFP) since 2002 when AKP reached power has made a great opening to the Arab World and pursues a disassociation from Israel. This is also a fact that puts limits to the option of transferring Israeli gas via Turkey. Finally, within the context of the U.S.-Russia competition over energy, Turkey does not seem to take sides, despite its NATO membership. On the contrary, what can be observed is a pro-Russian turn. Russia is becoming one of the largest investors in energy infrastructure in Turkey. Basic examples are the agreed nuclear power plant in Akkuyu and natural gas storage facilities in Salt Lake (Bilgin, 2010). As was also stated above, Turkey is also becoming an important customer of Russian military equipment despite NATO's objections. The purchase of the S-400 surface-to air missile system is a basic example (Gall \& Higgins, 2017). As a consequence, what under normal circumstances is expected in the longer run is the normalization and further strengthening of Turkish-Russian relations especially in the energy sector.

As a result, from an early stage, it is common knowledge among military leaders and policy-makers in Washington that Turkey should not be taken for granted as a viable and stable ally (Flanagan \& Brannen, 2008). The rejection of Turkish High National Assembly in 2003 to allow a U.S. invasion of Iraq from its soil was nothing else but the first serious indication. In addition, the signing of a memorandum of understanding in 2007 between Turkey and Iran to transfer 30 billion cubic meter of Iranian and Turkmen natural gas to Europe received strong criticism by the U.S. government (Samaan, 2016). Finally, President Trump's decision to recognize Jerusalem as the Capital of Israel in December 2017 resulted in further deterioration of Turco-Israeli diplomatic relations due to Tayip Erdogan's aggressive rhetoric towards Israel.

\section{The Second Option}

The second option for the export of Eastern-Mediterranean natural gas is by the construction of an LNG. One possibility is the construction of a floating LNG facility offshore of Israel and the second option is the construction of such a facility at Vasilikos on the Southern coast of Cyprus. In that case, gas will be brought with the construction of an undersea pipeline, via the Greek island of Crete to Europe (Cohen, 2015). A floating LNG facility, however, "would constitute an obvious target for missile attack by Hezbollah forces in Lebanon (Roberts, 2013; Inbar, 2014). An LNG at Vasilikos, an option that the RoC favours, has to be a joint LNG facility between Nicosia and Tel Aviv. This is due to the fact that the construction of an LNG is very expensive and as a result higher volumes of proven gas resources are required for its development to be justified. As was presented above, the gas resources that have been discovered so far within the EEZ of the RoC do not suffice to make such an investment financially viable, and thus, the gas resources of Israel and Egypt or part of it are required. The RoC though has already provided new drilling permits to international companies for further investigations for natural gas in its EEZ. In case, if those investigations are successful, its position in the regional energy politics will be significantly improved.

Moreover, an LNG facility whether at Vasilikos (Cyprus) or offshore of Israel will provide an alternative for Eastern Mediterranean gas resources to be exported to Asian Markets which are "recording prices closer to $\$ 15 \mathrm{mmBtu}$ in recent years compared to $\$ 9 \mathrm{mmBtu}$ of their European markets (Roberts, 2013; Inbar, 2014). This export alternative could possibly make an LNG facility at Vasilikos financially feasible. It should be bear in mind however that the high price for LNG at the Asian Markets was only temporal and was attributed to the nuclear accident of 2011 in Japan at Fukushima nuclear plant (Tanchum, 2015).

For Israel moreover, by including an LNG facility at Vasilikos as an export root for its gas resources will provide it with some foreign policy credits given that such an opening will bring it closer to countries like the 
$\mathrm{RoC}$ and Greece that traditionally have been closer to the Arab World. Over the last years, moreover during which Israeli-Turkish relations has deteriorated and the wider Middle East is experiencing upheavals mainly due to the Arab-Spring movement, Cyprus and Greece constitute a strategic outlet for Israel to the West.

\section{Limitations}

The second option, however, also faces some limitations. Firstly, Israel may be not willing to commit itself to one of the players (i.e., the RoC). At the same time, as long as the Cyprus issue remains unresolved, nobody can preclude the possibility of a conflict that will put the investment of the construction of an LNG facility at risk. Turkey has already raised tensions over the EEZ of the RoC. In particular, Ankara does not recognize the delimitation treaty of the EEZ signed between the $\mathrm{RoC}$ and Israel and between the $\mathrm{RoC}$ and Egypt. In particular, foreign policy-makers in Turkey argue that the Greek-Cypriot administration does not represent the Turkish Cypriots and Cyprus as a whole. However, this claim does not stand given that the only internationally recognized government of the RoC is that of the Greek-Cypriots. In February 2018, moreover Turkey prevented via its navy, the conduct of explorations by the Italian oil company ENI within the EEZ of the RoC.

At the same time, the cost of this second option is quite high. It is estimated at 10 billion euros ( $\$ 11$ billion) which would include the extraction and the transportation to Europe (Samaan, 2016). It worth to be mentioned that the cost of the first option (i.e., export via Turkey) is estimated at $\$ 2$ billion (Samaan, 2016).

\section{The Third Option}

The third option is for the Cypriot and Israeli natural gas to be exported to Europe via Egypt either through the existing pipeline that connects Israel with Egypt or via an undersea pipeline that will connect Leviathan and Aphrodite sea fields with Egypt. The main benefits of such an option is the fact, as was stated above, that Israel and Egypt are already connected with a natural gas pipeline and there is already an LNG facility operating in Egypt. Furthermore, as was also mentioned above, a great natural gas resource was discovered in the Zohr sea field in Egyptian waters in 2015. This development will make Egypt more attractive as an export root of natural gas to Europe. Furthermore, in case, the RoC discovers new gas resources in one of its sea fields close to Zohr, such a development will allow her to export part of its gas to Europe via Egypt's off shore LNG facilities at a much lower cost. It worth also to be mentioned that since 2014 a memorandum of understanding has been signed between the RoC and Egypt that enables the Egyptian Natural Gas Holding Company and the Cypriot Natural Gas Company to examine technical solution for the transportation of natural gas from Aphrodite sea filed to Egypt.

\section{Limitations}

As was the case with the previous options, there are some disadvantages with this third one also. The unresolved Cyprus issue also tops the list. Turkey does not recognize the delineation treaty signed between Egypt and the RoC on the EEZ. Furthermore, there is a deteriorating relationship between the present government of Egypt and Turkey. This deterioration took place after the ouster of the Muslim Brotherhood from power. Turkey is not in favour of the trilateral partnership between Egypt, Greece, and the RoC. As a result, Greek-Turkish relations, the problematic on high-politics issues, may also create future problems.

Is worth also to be mentioned that the pipeline which connects Israel and Egypt, in 2011 has been attacked by paramilitary groups. This event lead the Israeli government to stop its energy co-operation with Egypt (Good, 2014). This means that internal stability in Egypt is also prerequisite for the third option to be chosen. 
All in all, what can be observed from the above analysis of the three available options is that all of them have a common problematic denominator for their implementation. The section that follows will try to evaluate the prospects for the resolution of the Cyprus issue as a result of the energy factor. The question therefore that remains to be answered is whether the parameter of energy that has been added to the longstanding Cyprus issue can contribute to its resolution.

\section{Energy and the Resolution of the Cyprus Problem}

Since 1974 when Greek military dictatorship organized a coup against the Cypriot President Archbishop Makarios and Turkey launched a military invasion against the RoC, numerous unsuccessful rounds of negotiations for the achievement of a settlement have taken place. All these negotiations were based on the "high agreement" that has been reached in 1979 between the leaders of both communities that Cyprus should be reunited within the context of a bizonal and bicommunal federation. Most of these negotiations were under the aegis of the United Nations (UN). The hitherto most comprehensive attempt to turn this principle agreement to a political entity was the so called "Annan Plan" in 2004. This resolution plan that was named after the then Secretary General of the UN Cofi Annan was eventually rejected in a referendum by the Greek Cypriots who raised serious objections on the treaty of guarantee and on security issues. By that time, the accession of the $\mathrm{RoC}$ in the EU was considered as the main parameter that monitored all this process.

Today, many analysts of the Cyprus issue, including the president of the RoC himself, believe that the discovery of natural gas resources within the EEZ of Cyprus will motivated Turkey to compromise itself (Anastasiadis, 2016). This argument seems to be valid if one also bears in mind the Cold War between Russia and the U.S. over the energy market of Europe. At the same time, a resolution of the Cyprus problem at this point does not only serves the interests of the RoC, but also serves the interests of other actors directly or indirectly involved. It serves in other words the interests of Turkey, Greece, Britain, Israel, and the EU. The following section tries to analyse how the interests of the aforementioned actors are served by a mutually agreed settlement.

\section{The View from Ankara: High Cost of maintaining the Status Quo}

Without any doubt, the resolution of the Cyprus issue lies on a large extent on Turkey. Ankara, as was stated above, since 1974 illegally occupies $37 \%$ of the territory of the RoC and maintains military troops on the island. For Turkey, Cyprus is very important for various reasons. First of all, it perceives itself as the patron of the Turkish-Cypriot community. Tayip Erdogan himself has described this relationship as the one of a baby and a father (Hurriyet Daily News, 2017). Second of all, Ankara is fully aware of the strategic importance of Cyprus not only for itself but for great powers. Its proximity to its territory makes this importance even greater. Moreover, Turkey given that the majority of the population of the $\mathrm{RoC}$ is Greek Cypriots is afraid that by losing control of Cyprus, it will be circulated by Greece which perceives as its main regional competitor. Ahmet Davutoglou in his well known book where he analyses the strategic doctrine of Turkish foreign policy states that even no Turkish Cypriots were living on Cyprus, Turkey has to keep the Island under its control, otherwise, it will be circulated by Greeks (Davutoglou, 2010). In many respects, a combination of the aforementioned reasons lead Turkey to invade Cyprus in 1974 (Sözen, 2013).

Since then, however, the Cyprus issue constantly creates a political, financial, legal, and credibility cost for Turkey, which given the realities of modern international relations is bound to increased. In particular, 
Ankara's insistence on maintaining the role of an occupying power in Northern Cyprus has resulted in tentative relations not only with the RoC, but also with Greece. Furthermore, since 2004 when the RoC became a full EU member, the Cyprus issue has in many respects been Europeanized. As a result, EU-Turkish relations have been loaded with extra burden.

This implies further delays for the completion of the negotiations for Turkey's entrance in the EU. For example, as a result of Turkey's unwillingness to recognize the RoC, and thus, apply the additional protocol to Ankara's agreement for the Customs Union to her, has led the European Council in 2006 to frozen a great number of negotiations chapters. As the official site of the EU states, due to the Turkish failure to apply to Cyprus the Additional Protocol to the Ankara Agreement, the Council decides that eight relevant chapters will not be opened and no chapter will be provisionally closed until Turkey has fulfilled its commitment. The eight chapters are: Free Movement of Goods, Right of Establishment and Freedom to Provide Services, Financial Services, Agriculture and Rural Development, Fisheries, Transport Policy, Customs Union, and External Relations (European Commission, 2008).

Furthermore, the Cyprus issue creates cohesion problems to NATO given that Greece and Turkey are members of the Alliance. Sort after the invasion of Turkey to Cyprus, Greece withdrew from the military branch of NATO and the U.S. imposed an armed embargo on Turkey. The competition that was intensified between Turkey and Greece as a result of the Cyprus issue also created further problems to the Western Block. Turkey, in other words was exposed to its NATO allies as the "naughty child" of the Alliance.

In addition, the existence for decades of a Cold War between Greece and Turkey has lead to counter balance policies by Greece that have deteriorate Turkey's strategic environment in the area. Greece and Israel have improved greatly their co-operation elevating their relation to a strategic partnership. This strategic partnership took place after the deterioration of Turkish-Israeli diplomatic relations in 2010. Simultaneously, Greece, Cyprus, and Egypt have formed another alliance sort after "the ouster of Muslim Brotherhood from power to a development Turkey criticized ferociously (Tziarras, 2015)".

Meanwhile, the fact that Turkey is perceived by the international community and the UN as an occupying power of the $37 \%$ of the territory of the RoC exposes itself on persecutions for various ongoing violations of human rights. This implies that if the Cyprus issue will not be resolved Turkey "will be remained exposed to all kinds of international lawsuits and claims within the European human rights protection system (Bagdonas, 2015). In fact, a series of judgments on the Cyprus issue by the European Court of Human Rights (ECHR) stipulated compensations mounting to millions of euros for the displaced Greek-Cypriots who owned property in northern Cyprus but also for the RoC itself. Indeed, in Cyprus vs. Turkey, the ECHR ordered Turkey to pay 90 million euros in 2014 (Bagdonas, 2015).

Turkey also has to cover a great cost to support the internationally unrecognized Turkish Republic of Northern Cyprus (TRNC). "In some periods, aid and credit from Turkey amounted to over $12 \%$ of the Northern Cyprus GNP (Bagdonas, 2015)." At the same time, the maintenance cost of the occupation army despite the fact that is not revealed should also be high. "For comparison, the British Bases in Cyprus, which have more than 10 times fewer personnel, cost 212 million pounds in 2012 (Bagdonas, 2015). At the moment, given the difficult economic situation in Turkey, support from Turkey to the so called TRNC should not be expected at the same extent as in the past.

Within this context, the discovery of natural gas within the EEZ of the RoC further adds to Turkish cost of maintaining the status of an occupying power in Northern Cyprus. As was argued in the previous sections, the 
export route for Cyprus and Israeli natural gas will be better served if there is a resolution of the Cyprus issue. In this case, Cyprus will facilitate the exportation of at least Israeli gas to Turkey through its EEZ. In that way, Turkey will lesser its heavy dependence on Russian and Iranian gas, and thus, will become both conveyor and buyer gas. Iran, as was mentioned above, is the second largest natural gas exporter to Turkey (Babaly, 2012). Simultaneously, Ankara will be able to further improve its relations with Tel Aviv and serve its foreign policy goal of becoming an energy hub. In addition, a possible resolution of the Cyprus issue that will facilitate the export of gas to Europe will serve the energy security interests of the EU, will contribute to the continuation of the rapprochement process between Greece and Turkey, will increase the strategic importance of Turkey and will eliminate most of the political, economic, legal, and credibility cost that the occupation of the northern Cyprus implies for the government of Ankara. Furthermore, a substantial Turkish contribution to the resolution of the Cyprus problem will enable the government of Ankara to demonstrate to its "traditional western allies" that its alignment with Russia and Iran on energy issues "is complementary rather than contradictory to western policies and is just a part of its ambition to become a vital east-west and north-south energy bridge (Babaly, 2012).

On the contrary, Turkey's insistence for the maintenance of status quo on Cyprus and its alignment with Russia and Iran will make the other actors concerned (Greece, the RoC, Britain,Israel, the U.S., and the EU) not only to continue their support for the formation of regional alliances against Turkey, like Cyprus, Greece, Egypt, Greece, Israel, and Cyprus but also to exclude the prospect of an export root of the East-Med via its territory. This will imply not only a strategic loss for Ankara in its aspiration to become an energy hub but also the strengthening of its regional competitors.

\section{The View From Athens in Crisis}

It is common knowledge among Greek political and military elites as well as academics and various other analysts that a substantial improvement of Greek-Turkish relations will take place only when the Cyprus issue will be settled (Koukoudakis, 2013). For Greece, in a period of an extreme financial crisis, good neighborly relations with Turkey imply a lower defense budget and thus a curtailment of the financial burden of armaments. At the same time, since 1999 Helsinki EU Summit Greek-Turkish relations have experienced an unprecedented improvement in low-politics areas that have delivered mutual benefits (Koukoudakis, 2015). The resolution of the Cyprus issue in a mutual accepted manner will also be conducive to the healing of the psychological trauma of the past.

At the same time and most important perhaps, Greek-Turkish energy co-operation, as a result of the rapprochement process of 1999, has a great potential. In 2007, as was pointed above, the interconnector to Greece was opened. It is an interconnector pipeline that carries Caspian gas via Turkey to Greece. Its importance lies on the fact that for the first time gas from the Caspian reaches Europe without crossing Russian territory (Barysch, 2007). Furthermore, in 2008 the electricity grids of both countries were linked as a result of a memorandum of understanding that was signed in 2002 between DEH, Greece's Public Power Corporation, TEIA, and Turkish Transmission System Operator. In addition, in 2012 the Turkish government signed with its Azeri counterpart an agreement for the construction of the TANAP. This pipeline is going to carry gas to Europe via Turkey and is expected to be operational in 2018. Within this direction, the Shaz Deniz Consortium signed an agreement to construct the TAP that is going to connect TANAP with Europe via Greece, Albania, and Italy. The importance of this project was also confirmed on the high level energy dialogue between EU and 
Turkey. As far as this project is concerned, the EC underlines that "TANAP is of vital importance for the EU's and Turkey's security of supply and for the realization of the Southern Gas Corridor (European Commission, 2015b)".

Greece's aspiration to serve as an energy hub also depends on a large extent on its co-operation with Turkey. This co-operation requires good neighborly relations with Ankara. In that way, Greece is also contributing to the energy security of the EU. Simultaneously Athens also serves NATO's interests since is contributing to the strategy of its leading power to deter further Russian expansion to the Energy market of Europe. Good Greek-Turkish relations also preserve the cohesion of NATO. Furthermore, an export root for the South-East Mediterranean gas that also involves Greece will further strengthen its geopolitical position not only within the EU but also within NATO. At the same time, Greek ship-owners are expecting great profits from the transportation of LNG. Only in 2013, \$4 billion investments on new LNG ship carriers have been made by Greek Ship-owners (Greek Energy Portal, 2014).

From the above it can be argued that is also in Greece's interests to contribute to the resolution of the Cyprus issue. This however, does not imply that Athens will sacrifice vital national interests but that is also willing to reach a compromise.

\section{The View From London After "Brexit"}

Britain has obvious strategic interests in Cyprus that date back to 1878 when it assumed controlled of the island. During the Cold War, control of Cyprus was of paramount importance for NATO. Even nowadays, Cyprus is like an unsinkable aircraft carrier in the sensitive strategic area of Southeast Mediterranean. The UK still maintains military bases on the Island and still serves as a guarantee power for the independence and the territorial integrity of the RoC. Currently, British aircrafts are operating from the Akrotiri base against the so called Islamic State. Within this context, Britain takes what it really wants from Cyprus, and thus, it could be assumed that is not interested in the resolution of the political problem of the Island.

The situation, however, is not that simple. The UK, since its decision as a result of a referendum in November 2017, to exit from the EU, has to re-orientate its foreign policy priorities. Within this context, British foreign policy choices are expected to come closer to those of the U.S. It is not a coincidence that the first foreign leader that visits the newly elected American President Donald Trump was the new Prime Minister of Britain Teresa May. Within this context, the UK has to further contribute to U.S. strategy of decreasing Russian influence in the energy market of Europe. Contributing to the strengthening of NATO's southern flank and even pressing for Cyprus inclusion under NATO, security umbrella will not be perceived as a surprise. In addition, UK has to demonstrate to the international public opinion that is no longer adhered to post-colonial policies (i.e., maintaining control of ex-colonies through divide and rule policies and military bases that violate, the right of internal self determination of the Cypriot citizens who live within them).

\section{RoC: “The Victim's” Point of View}

The $\mathrm{RoC}$ and its people both Greek and Turkish Cypriots are obvious the victims of the military intervention that was staged by Turkey in 1974. The illegal occupation of one third of its territory led to a massive displacement of people (Turkish and Greek Cypriots) who were deprived their properties, their working place and their religious and cultural monuments. At the same time, the fate of most of the 1.619 missing Greek Cypriots since 1974 is still unknown. 
After over 43 years of military occupation of $37 \%$ of its territory and numerous unsuccessful negotiations for a resolution of this issue, the $\mathrm{RoC}$ has become an "awkward" sovereign state, member of the UN and the EU that is still subject to intervention rights and guarantees by third countries. It is also obliged to accept the presence of military bases that cover $2 \%-3 \%$ of its territory.

The $\mathrm{RoC}$ is thus the only party that more than anyone else is aiming to a resolution that will lead to its reunification. Within this context, the discoveries of gas reserves to its EEZ add some more motives for a settlement. A settlement of the Cyprus issue will enhance the safety of the investment of the exploitation of gas. Without any doubt, both of the constituted communities of the republic will be benefited and thus peace among them will be further consolidated. Furthermore, in 2014 the Cyprus Centre of the Pease Research Institute Oslo (PRIO) conducted a research according to which the gross national product of a reunited RoC would be more than double from 2012 to 2035 (Wriebning, 2016). Furthermore, according to Noble Energy, the RoC only from the exploitation of the "Aphrodite" natural gas reserve is expecting profits amounting to $\$ 550$ million annually (Noble Energy, 2017).

In this case, given that most of the parties concerned are NATO members, Cyprus could also join NATO and thus strengthen its southwestern flank. In this case, NATO could also become a guarantor organization of the territorial integrity of the RoC. In addition, within the context of the Cold War that was described above, most of the parties concerned would support such a development given that have stronger links with NATO and the USA in particular. The discoveries of great quantities of natural gas at Zhor sea field can also make the RoC to consider its energy co-operation with Cairo and the creation of an export root from Egypt to Europe. In that case, the RoC will definitely enhance its diplomatic leverage in European and International politics for the resolution of its longstanding problem.

\section{Israel: The New Important Factor in the Cyprus Issue}

Israel is an important country not only for the area of the South East Mediterranean and the Middle East but also for global politics in general. Its special relation with the U.S. and its partnership with NATO in combination with its powerful and influential diasporas enables it to exercise important influence in regional and global politics.

The discovery in 2010 of huge quantities of gas in the Leviathan sea field in its EEZ renewed its political interest for the area of South East Mediterranean. Since then, Israel, as was stated above, tries to set efficient and safe exports outlets for its gaz.

Tel Aviv, despite its deteriorated political and diplomatic relations with Ankara, seems to be demonstrating political realism in order to serve its wider geostrategic interests. First of all, one should bear in mind that a big part of Israel's oil supply continues to arrive via the Turkish port of Ceyhan. Furthermore, from 2009 to 2014, a very bad period of the diplomatic relations between the two countries, the volume of Turkish-Israeli bilateral trade was doubled, from $\$ 2.66$ billion dollars to $\$ 5.62$ billion dollars. Furthermore, Turkish seaborne exports to the Middle East were performed through Israeli ports (Tanchum, 2015).

Moreover, in many respects, Israel perceives Iran as one of its main regional strategic competitor. Within this context, Tel Aviv, and Ankara as well, developed strategic economic and security co-operation with Azerbeitzan. Azerbaitzan is another energy producing country with which, as was stated above, the EU is aiming to diversify its suppliers and the roots of supply, and thus, lessen its energy dependence on Russia. "The proposed initial volume of Israeli natural gas to be exported to Turkey is equivalent to $29 \%-37 \%$ of the total volume that Turkey imported from Russia in 2014 (Tanchum, 2015). 
Within the context of the undeclared Cold War over energy, this implies losses in economic and diplomatic terms for both Russia and Iran. As was stated above, Iran is the second largest natural gas exporter, after Russia, to Turkey. At the same time, Israel contributes to the U.S. foreign policy goal of curtailing Russian and Iranian influence expansion through energy in the region. Tel Aviv over the last years has evolved into one of the largest commercial partners of Baku. Almost $40 \%$ of Israel's imported oil derives from Azerbaijan. Their cooperation also expands to the defense sector. In 2012, an $\$ 1.6$ billion arms supply agreement was signed between them (Samaan, 2016). Azerbaijan surely has an interest in hedging against Iran, as the regime in Tehran remains a key ally of Armenia (Samaan, 2016).

Nobody, however, can guarantee that Turkey will adhere to this line of foreign policy. Its recent alignment with Iran (2017), Israel's opponent in the area, against the Kurds of Iraq, its rapprochement with Russia, and the purchase of surface-to air missile system (S-400), in combination with its recent objection for the resolution of the Cyprus issue (Summer in 2017) raise a lot of uncertainty not only for Tel Aviv but for NATO as well. In other words, Turkish Foreign Policy is not any more tuned with its traditional western allies and therefore should not be taken for granted anymore its adherence to "Cold War" strategies and especially to U.S. policies to check Russia's resurgent energy policy in Eurasia.

It worth also to be mentioned that until 2015, Egypt was considered in the lead to become another market outlet for Israel's natural gas. Its excellent diplomatic relation with the RoC and Greece that has lead to the delimitation of their EEZ's, the shallower crossing of a natural gas pipeline from Israel to Egypt, the existing LNG facilities in combination with good relations between Tel Aviv and Cairo were factors that were pushing towards this direction.

Furthermore, in 2015 Egypt announced that a great quantity of natural gas was discovered in the Zohr field off its coast. "The Zohr field is 36\% larger than Israel's Leviathan field and the largest natural gas field in the Eastern Meditteranean (Samaan, 2016). This discovery will enable Egypt not only to satisfy its domestic natural gas demand but also to become a net exporter. This implies that Israel will not have to consider Egypt as a customer for its natural gas but mainly as an export root. As a result, given the experiences of the past events in Egypt within the context of the Arab Spring, it will be wise for Israel not create a dangerous dependency for its natural gas export root (Ghafar, 2015).

As was also stated above, Israel is also considering Cyprus as an export root for its natural gas. So far, Cyprus also needs Israeli natural gas not only to make an LNG facility at Vasilikos financially feasible but also to increase its interdiction capability towards Turkey. However, the unresolved political problem of the RoC in combination with Turkish threats put also some limitations on Tel Aviv choices.

As was aforementioned, Israel is a regional power with strategic and security interests beyond the South-East Mediterranean region. It has from one hand to face its main competitor in the region of the Middle East (i.e., Iran) and thus needs Turkey and has also to contribute to U.S. policies (i.e., to curtail the expansion of Russian influence in international energy politics). Within this context, it seems that is in Israel's interest to use all the possible choices for the export root of its gas not only for economic but mainly for political and geostrategic reasons. For this prospect to be realized, however, the Cyprus issue has to be resolved. As a result, Israel in a way becomes another important actor for the resolution of the longstanding Cyprus issue. 


\section{Conclusions}

All in all, from the above analysis, it can be argued that energy is a new and very important factor in the Cyprus issue. Within the context of "the never ending Cold War over energy," the discovery of great gas resources in Eastern Mediterranean can provide a serious impetus for the resolution of the Cyprus issue in a positive sum way at least for the parties that are traditionally allied with the West. In a way, the energy factor comes in the right time. It can be argued that energy is replacing the EU membership factor that provided an impetus for the resolution of this longstanding political problem in 2004. Since then, however, the EU has lost credibility in the eyes of the main actors concerned given that the RoC has acquired full membership status and thus can influence the Union's attitudes towards Turkey and probably towards UK after brexit (Kyris, 2012). Small states after all, like the RoC develop the tendency to pursue their foreign policy goals through participation in various international organizations and alliances (Koukoudakis, 2011).

In other words, the energy factor comes to replace the EU membership factor for Turkey and thus provide a basis for a viable and functional resolution of the Cyprus issue. Also, energy revives American interest for the area. Obviously, U.S. strategy towards an uprising Russia is to impede the increase of its political and economic leverage in Europe. Energy seems to be an effective Russian political instrument. As a result, Washington is expected to have a positive contribution towards the resolution of the Cyprus issue in order to enable a Mediterranean energy corridor to be created which will lessen EU's energy dependence on Russia. Furthermore, the South Energy Corridor besides its short quantities will be also exposed to regional geopolitics. Issues such as Ajerbaitzan and its tentative relations with Armenia over Nagorno-Karabakh, the Russian -Georgia relations and the frozen conflicts in Ossetia and Abkhazia, the Iranian nuclear issue, the future of Iraq and relations with the Kurdish Regional Government are important factors that can negatively influence energy politics and thus put Turkish and European energy security in jeopardy. Within this context, the creation of a South-East Mediterranean energy corridor followed by a resolution of the longstanding Cyprus issue will be at the benefit of all parties concerned. Thus, U.S.'s traditional allies Greece, Britain, Israel, and the EU, including the $\mathrm{RoC}$, are expected to have a positive contribution towards this direction. The position of Turkey at the moment seems to constitute an enigma. Whether Turkey will maintain its maximalist position or will realize the benefits of a resolution is something that policy-makers and political leaders in Ankara have to clarify. If foreign policy-makers in Turkey really want to prove that alignment with Russia and Iran is complementary rather than contradictory to Turkey's western allies, Cyprus is a case in point that such an intention can be demonstrated. Multiplicity, after all (i.e., no conflicting foreign policy with other great powers), was one of the main principles of Ahmet Davutoglu's doctrine for Ankara's external relations. There is no doubt that a mutually beneficial co-operation on energy could serve as a stabilizing mechanism for the security complex of the South-East Mediterranean. For this to happen, however, the resolution of the Cyprus issue is required. It remains to be seen whether strategic rational will prevail over emotional and irrational considerations among all the actors involved.

\section{References}

Anastasiadis, N. (2016). The supply of gas, motive for Turkey. In Kathimerini Newspaper (p. 12). Kathimerini.

Babaly, T. (2012). The role of energy in Turkey's relations with Russia and Iran. In The Turkey, Russia, Iran Nexus: Economic and Energy Dimension (p. 6). Ankara.

Bagdonas, A. (2015). Turkey in Cyprus: Changing the status quo. European Journal of Economic and Political Studies, 8, 83-94. 
Barysch, K. (2007). Turkey's role in European energy security. Retrieved from http://www.cer.eu/sites/default/files/publications/attachments/pdf/2011/essay_turkey_energy_12dec07-1381.pdf

Bilgin, M. (2010). Energy and Turkey's foreign policy: State strategy, regional cooperation and private sector involvement. Turkish Policy Quarterly, 9(2), 82-92.

Cohen, A. (2015). How the Eastern Mediterranean could supply natural gas to Europe. Retrieved from https://blogs.wsj.com/experts/2015/04/03/how-the-eastern-mediterranean-could-supply-natural-gas-to-europe/

Cordesman, A., \& Al-Rodhan, K. (2006). The global oil market: Risks and uncertainties. Washington, D. C.: Center for Strategic and International Studies.

Davutoglou, A. (2010). The stategic depth. Athens, Peotita Pubications. (Translated in Greek)

EU. (2009). The declaration: Prague summit, southern corridor. Retrieved from http://www.eu.2009.cz/en/news-and-documents/press-releases/declaration-prague-summit-southern-corridor-may-8-2009-21 533

EU. (2015). Energy security $\quad$ strategy. $\quad$ Retrieved from http://ec.europa.eu/energy/en/topics/energy-strategy/energy-security-strategy

Euractive. (2009). Turkey plays is energy card in stalled EU accession talks. Retrieved from http://www.euractive.com/enlargement/turkey-plays-energy-card-stalled-eu accession-talks/article=178623

European Commission. (2000). Towards a European strategy for the security of energy supply. COM 769 Final.

European Commission. (2006). A European strategy for sustainable, competitive and secure energy. Retrieved from http://europa.eu/documents/comm/green_papers/pdf/com2006_105_en.pdf

European Commission. (2008). European neighbourhood policy and enlargement negotiations. Retrieved from http://ec.europa.eu/enlargement/candidate-countries/turkey/eu_turkey_relations_en.htm

European Commission. (2011). Key Figures, Market Observatory for Energy. Directorate General for Energy, June 2011.

European Commission. (2014). European energy strategy: Communication from the commission to the European parliament and the council. COM 330 Final.

European Commission. (2015a). Energy union package: A framework strategy for a resilient energy union with a forward looking climate change policy. Brussels: Author.

European Commission. (2015b). EU-Turkey high level energy dialogue and strategic energy cooperation. Retrieved from http://ec.europa.eu/commission/2014-2019/arias-canete/announcements/eu-turkey-high-level-energy-dialogue-and-strategicenergy cooperation_en

European Union (EU). (2003). European security strategy: A secure Europe in a better world. Brussels: Author.

Flanagan, S., \& Brannen, S. (2008). Turkey's shifting dynamics: Implications for U.S.-Turkey relations. Washington, D. C.: Center for Strategic and International Studies.

Gall, C., \& Higgins, A. (2017). Turkey signs Russian missile deal, pivoting from NATO. Retrieved from https://www.nytimes.com/2017/09/12/world/europe/turkey-russia-missile-deal.html

Gawdat, B. (2006). Europe's energy security: Challenges and opportunities. International Affairs, 82(5), 963-964.

Ghafar, A. A. (2015). Egypt's new gas discovery: Opportunities and challenges. Brooking Doha Center.

Good, A. (2014). East Mediterranean natural gas and Israel's regional foreign policy. In IMES Capstone Paper Series (p. 9). The Institute for Middle East Studies, The George Washington University.

Greek Energy Portal. (2014). Orders of \$4 billion dollars for ships LNG-LPG from Greeks in 2013. Greece Energy Press.

Hurriyet Daily News. (2017). Turkey, Cyprus and Patriarchy. Retrieved from http://www.hurriyetdailynews.com/opinion/mustafa-akyol/turkey-cyprus-and-patriarchy--81670

Inbar, E. (2014). The new strategic equation in the Eastern Mediterranean. In Mideast Security and Policy Studies (No. 109). Begin-Sadt Center for Strategic Studies.

Kaysi, H. (2011). Energy security of the European Union and Turkey's role. Ankara Review of European Studies, 4(2), 63-82.

Koukoudakis, G. (2011). European integration, small states and the limits of the neorealist paradigm: The case of Cyprus (EU research monographs, Hellenic Center for European Studies).

Koukoudakis, G. (2013). Greek-Turkish rapprochement and Turkey's EU membership quest: Turning rhetoric into reality. Turkish Policy Quarterly, 12(2), 157-166.

Koukoudakis, G. (2015). Explaining the endurance of Greek-Turkish rapprochement. International Relations Academic Journal, 11(44), 81-100. 
Koukoudakis, G. (2017a). EU energy security and turkey's contribution to the southern energy corridor. Mediterranean Quarterly, 28(2), 106-124.

Koukoudakis, G. (2017b). Authoritarianism in Turkey: From Kemalism to Erdoganism via democratic reforms and economic development. Roumanian Journal of History and International Relations, 4(1), 63-102.

Koukoudakis, G., \& Pieper, M. (2014). Turkish political culture from Kemal Ataturk to Tayyip Erdogan: From forced secularism to subtle Islamisation to European alienation (Research monograph, Hellenic Center for European Studies).

Kyris, G. (2012). The European Union and the Cyprus problem: A story of limited impetus. Eastern Journal of European Studies, $3(1), 87-99$.

Noble Energy. (2017). Eastern Mediterranean report. $\quad$ Retrieved from $\mathrm{http}: / / \mathrm{www}$. nobleenergyinc.com/operations/eastern-Mediterranean-128.html

Republic of Turkey Ministry Foreign Affairs. (2017). Turkey's energy strategy. Retrieved from http://mfa.gov.tr/turkey-energy-strategy.en.mfa

Roberts, J. (2013). Engaging Turkey: A venues for cooperation between Turkey, the EU and the U.S. in regard to Eastern Mediterranean energy. In Briefing Paper (p. 3), Brookings Institute.

Roberts, J. (2015). Russia and Turkey: Aerial combat and energy security. Retrieved from $\mathrm{http} / / /$ www.euractiv.com/sections/energy/russia-and- turkey-aerial-combat-and-energy-security-319841

Samaan, J. L. (2016). The East Mediterranean triangle at crossroads. In The Letort Papers (p. 16). Carlisle, PA: Strategic Studies Institute, U.S. Army War College.

Savvides, P. (2015). Cyprus oil and the energy game in the Eastern Mediterranean. Retrieved from $\mathrm{http}$ //www.thetoc.gr/eng/politics/article/analysis-cyprus-oil-and-the-energy-game-in-the eastern Mediterranean

Shaffer, B. (2006). Turkey's energy policies in a tight global energy market. Insight Turkey, 8(2), 97-104.

Smith, K. (2010). Russia-Europe energy relations: Implications for U.S. policy. Washinghton, DC: Center for Strategic and International Studies.

Sözen, A. (2013). Turkey's New Cyprus policy: Transforming a military base into a basin of cooperation. In E. C. Sokullu (Ed.), Debating security in Turkey (pp. 109-122). London: Lexington Books.

Tanchum, M. (2015). A new equilibrium: The Republic of Cyprus, Israel, and Turkey in the Eastern Mediterranean strategic architecture. In Occasional Paper Series 1 (p. 8). Peace Research Institute, Friedrich Ebert Siftung.

Tekin, A., \& Williams, P. (2009). Europe's external energy policy and Turkey's accession process. Center for European Studies Working Paper Series, 179, 7.

Tsakiris, T. (2014). Dependecies and vulnerabilities: The energy parameters of the evolving crisis between Russia the EU and Ukraine. ELIAMEP Working Paper, 43, 9.

Tziarras, Z. (2015). The new geopolitical landscape in the Eastern Mediterranean: The Isareli perception. Eastern Mediterranean Geopolitical Review, 1, 32-43.

U.S. Department of State. (2017). Bureau of energy resources. Retrieved from https://www.state.gov/e/enr/

Wriebning, T. (2016). Cyprus: Is one of the oldest conflicts about to be resolved? In Security Policy Working Paper (No. 5, p. 3). Federal Academy for Security Policy. 